University of Nebraska - Lincoln

DigitalCommons@University of Nebraska - Lincoln

$11-1925$

The Value of English Linguistics to the Teacher

Louise Pound

Follow this and additional works at: https://digitalcommons.unl.edu/englishfacpubs

Part of the Comparative Literature Commons, English Language and Literature Commons, Modern Literature Commons, and the Reading and Language Commons

This Article is brought to you for free and open access by the English, Department of at DigitalCommons@University of Nebraska - Lincoln. It has been accepted for inclusion in Faculty Publications -Department of English by an authorized administrator of DigitalCommons@University of Nebraska - Lincoln. 


\section{THE VALUE OF ENGLISH LINGUISTICS TO THE TEACHER ${ }^{*}$}

I

$\mathrm{W}$ HAT is included in the usual course in the history of the English language? Presumably some teachers emphasize the translation of older monuments, some emphasize training in etymologies, some phonetic changes, and some changes in language structure and forms. Some offer courses in the hope of fostering a more accurate use of language, some because of the discipline to be gained from the study of language in the abstract, and some in order to afford the necessary preparation for the scholar. All have in mind the development, on the part of the student, of a scientific attitude toward language.

Any teacher is the better who has background in the subject which he teaches, and he teaches it the more inspiringly and the more validly for having that background. The exhaustive study of philological details belongs to the advanced student and to the specialist. For the average student of the language, it is of less importance to "settle Hoti's business" than to understand the relation of existing linguistic forms to the language in general, and to acquire a deepened linguistic consciousness. Except for the ultra-specialist, the consideration of a multiplicity of details (though command of details and accuracy in details are always important) may well be subordinated to the establishment of main lines and the opening up of new

IRead before the College Section of the National Council of English Teachers, St. Louis, 1924. fields. A main benefit of the historical study of English is that it enbances linguistic sensitiveness and brings a wider linguistic borizon.

The historical student of language develops a perspective beyond that of the ordinary student. Many teachers and students have little perspective back of Shakespeare; certainly little back of Chaucer. One is familiar with a type of teacher of literature who casually and rather patronizingly groups together Chaucer and Shakespeare and Pope as "old authors." In the same way, many teachers think of anything behind the language of the nineteenth century as "Old English," without discrimination and without a sense of development. Surely, in any subject the cultivation of a sense of chronology is desirable. Those who teach present-day English can do so mote broadly and more accurately if they have a knowledge of beginnings as an approach to the contemporary, much as those who teach current history do so to better advantage when they know something of the past.

In general both the teacher and the student need the idea of development in language. The doctrine of evolution finds illustration in the study of language as well as in the study of sciences like zoology and botany. A curious assumption that language is static is still to be found sometimes among teachers as among the laity. Many words which were in doubtful usage when they went to college are standard now; yet they bar their pupils from employing them. Many 
idioms which were not accepted then are accepted now, and many which were accepted once are now outworn. The same is true of many pronunciations. The static teacher persists in the usages he was taught in his school days and rejects their successors. The teacher of any phase of language work who is to handle his subject in the best way should have had experience with the evolutionary point of view, whether dealing with general principles or with details. As suggested in the opening paragraph, he needs a scientific attitude toward language.

\section{II}

There are four leading phases of the study of the English language to which the idea of development may be applied. They will be reviewed in the following pages and considerable illustrative matter introduced, in an attempt to show the living interest of the subject. They concern vocabulary, spelling, grammatical forms, and pronunciation.

$x$. It helps any teacher to have followed the growth of the English vocabulary. The capabilities of the language are better appreciated by one who has reviewed the strata entering into it and discriminated between the fundamental vernacular elements and the elements borrowed from other languages. It brings sounder judgment and larger toletance to realize that word-meanings are not stationary, and that the number and the kinds of words we employ are not stationary. There is an intensely human interest in words. Their life reflects the life of the race, and the customs and thoughts from which they have arisen. Shifts in vocabulary are always under way. It is of value culturally to survey the growth of our speech from its varied sources, to win sound ideas of the birth and death of words, and of the transformations they undergo and the reasons for these transformations. Even those who prefer to take into account only the living language may profit by experience with linguistic analysis. They will find their interest in words and their powers of observation enhanced. To pause for concrete illustration, how interesting, to the trained student, are the chief living sources for the replenishment of language, other than borrowing.

(I) New words may be floated by the individual who coined them, as folk-lore (instead of "popular antiquities") by W. J. Thoms in 1846 , or constutuency by Macaulay, or bypnotism by Dr. Braid, or enternational by Bentham.

(2) New words may come from proper names, as Zeppelin, pasteurize, silbowette, boycott.

(3) They may arise from the shortening for convenience of longer words, as curio from curiosity, wan from caravan, or patter from paternoster.

(4) They may arise through arbitrary blending as electrocute from electric and execuse, or the townname Calexico from California and Mexico. This form of word-coinage is relied on heavily in these days, in the language of commerce. Witness Sealpackercbief for a sealed packet of pocket hankderchiefs, or Senigenic mop.

(5) They may arise through reduction, as ma $a m$ from the Latin mea domina, a term of address which, in the most drastic reduction I know, becomes the $m$ of $Y_{e s} m$.

(6) They may arise through misconception or carelessness. For example, will lasndered pass into laundried, as it seems to be trying to do? What will be the fate of the four forms of alumnus, masculine and feminine, singular and plural? The American Association of Collegiate Alumnae is said to have changed its name partly because of the impossibility it experienced in getting newspapers and the public to reproduce its name accurately.

(7) New meanings may arise for old words, floated by slang usage, or by popular stage plays or by vaudeville or by films. How curious is the history of the word sbeik which has popularized itself in a new meaning before our eyes, as it were, or the developments of the word date from the meaning "a point of time" to the significance of a "social engagement" and now into an agent-noun "escort." "My date was late last evening."

(8) They may be coined arbitrarily to name some new invention, or they may be brought in from some foreign language. Witness new words like radio, phonograph, garage, or the popularization in recent times of the suffix -fest from the German, in the making of new compounds. 
(9) They may come through interchange of the parts of speech, as infinitives which become nouns, e.g., divide, cut, burn, meet, and recently sing. Sometimes these infinitives transformed into nouns are found mostly in the plural, as ears, weeps, feeds, smokes. Even an adjective may become a verb, as to wireless. Like is trying hard to become a conjunction. One hopes it will fail.

(10) They may be built from old words by the employment of suffixes, new or old, as our recent journalistic clubster, speedster, swimmist, writtist, or our new feminines in -efte, or -ine, like slackerette, actorine. I have heard the detestable pep, itself a shortening of pepper, extended to a verb, to pepify, and even to a noun of action, "Our football team needs pepification."

(II) The meanings of standard words may change-often slowly and almost unnoticeably, as prone is changing from the opposite of supine to the meaning merely of fat. Other words that have changed or are changing from their literary meanings are fix, nice, smart.

(x2) Standard words may be used in dialect ways. It is not only a pronoun, neuter in gender, but in games it has also a noun function, as it in "You're It" of the game of tag. In another usage, a slang usage, it means simpleton or booby. Who and which are taking on comparatives, in the English of the films, "Than whom none is wbomer," "Than which nothing is wbicber." Worse is used as a positive, "Noi so worse," and mucb as a poun, "Not such a mucb."

2. It is also of interest to watch the changes in grammatical forms in the light of parallel changes which have made their way in the past. One doubts whether there will be in the future many important changes in pronouns or adjectives or in verb formations. The vocabulary will always be undergoing changes but probably our language in its main lines will remain for centuries very much what it is now. Literary culture allows tolerance in vocabulary, but for grammar its tendency is strongly conservative. The making of our grammar, unlike the making of our vocabulary, is probably very nearly a finished process. Nevertheless some changes are always going on in the inflectional forms of words. For example the past participle broken has lost its $-n$ in one meaning and broke is now with us to stay with a meaning of its own. The optative is disappearing or has gone. It is conceivable that me, $u s$, bim, might sometime achieve standard usage in the nominative, as happened long ago with the dative-accusative you. As for nouns, the historic plural folk has a new form with $-s$, which arose alongside it, i.e., folks. One even hears in these days the double plural folkses, and there have been attempts to create therefrom an adjective folksy. Movieses and toeses are sometimes heard, new double plurals like the now orthodox traces, truces, bodices, kine, sixpences or children. One hears attempts at new singulars, like a corp, a bo-no more eccentric than were a pea or a cberry. Occasionally plurals are treated as singulars, a woods, a ways. The latter locution is well on its way toward acceptance and is no more illogical than the now accepted a means, a links, a play-grounds, a sbambles, an amends. Curriculums is now superceding curricula, and cactuses, cacti. Data and insignia are trying to be singulars. Have these phenomena educational interest? The cultural is what enriches life, and increased interest in human speech enriches life. It may be contended that matters of linguistic change belong to culture, along with changes in taste in reading matter and in art or music, and in their techniques.

The historical study of English does a genuine service in lighting up the subject of grammar, whether the matter involved be our modes of forming noun plurals, our patterns of verb conjugations, our comparisons of adjectives, or matters like the existence of the adverbial the, or the to infinitive, or curious single expressions like "a great many men," "Our Father wbich art in heaven," or dialect expressions like "That is aum," or "Tbem books." 
3. The bistorical study of spelling is also of value to the student of language. Differences between British and American spellings are to be taken into account in a few instances, as in the spelling of bonor, labor, etc., judgment, controller, inquiry, jail, tire, cbeck, gypsy, which may be British bonour, labour, etc., judgement, comptroller, enquiry, gaol, tyre, cheque, gipsy. There are renaissance respellings like debt, doubt, victuals. There are words which have their spellings from one dialect and their pronunciations from another like busy, which is spelled with $u$ but pronounced with $i$, or the placename suffix -bury, which is spelled with $*$ but pronounced with $e$; and there are words which owe their orthography to one foreign language and their pronunciation to another, like colonel, which has its written form from the Italian and its spoken form from the Spanish. Undue reverence for traditional spellings vanishes when one has followed erroneous respellings like those of ghost and aghast. There is much of everyday interest in the history of orthographical forms. What are the permanent traces of the late simplified spelling movement? They grow fainter in the standard language but have made a permanent impression on the language of advertisement, and therefore may later affect the standard language. Witness plurals like trunx, chix, inx, or the vogue of $k$, "We Klean Klothes Kwick," "'Klassy Kollege Kut Klothes"; or simplifications like "R U Going to Robbers' Cave?", "U-Rub-ItIn Ointment," "Will U C Smith for Paper-Hanging?" or "Wear-U-Well Shoes"; or the vagaries like "nuf sed, tuf, crool, likker, fizzical culture, of the columnists.

4. To be taken into account likewise is the matter of pronunciation. Here also the conception of the development of language is needed by the teacher. Spoken language shows even more rapid evolution than does written language. Pronunciation never stands still. Sound-shifting is going on constantly, for people are not alike, and they live under different conditions. A new generation never speaks exactly as the old, but develops slight variations. The same people do not always speak in the same way, nor is any one sound the same in the mouths of many people, nor always the same in the utterance of one person. In one period of years several usages may be allowable, one of which may in time prevail over others. These changes in the spoken language come gradually and unconsciously but they are inevitable and the teacher should realize it, else he is likely to be too rigid in his positions, and too servile to the authority of older dictionaries and orthoepies. Conservative dictionaries might insist upon per'emptory long after most speakers said peremp'tory, or demand Wistar'ia when most speakers say Wisti'ria; or fail to realize that ally, survey, details, are trying to change their accent to the first syllable as did balcony, which in the eighteenth century had its accent on the middle syllable. They urge us to say lit'erature' when the academic world says lit'erature, slurring the last syllable. One teacher (British) is said to have wished her pupils to say moun' tain', foun'tain', because she thought that "justice should be done to the last syllable of these words."

Unless guided to a realization of it, many speakers do not know that British and American English are no longer identical in pronunciation. Many words, e.g., again, been, trait, scbedule, squirrel, lieutenant, cantonment, are pronounced in one way in this country and in another way in England.

A teacher who has developed a sense of 
proportion through the historical study of pronunciation, or through phonetics, is not the type of teacher to give hours of class-room time to inculcating a few pronunciations like "don't | you," or "Not | at | all," or to insistence on an "intermediate" $a$ in aunt, while he does not mind the front vowel in parallel words like can't or plant. He does not exact an unvarying pronunciation for words like advertisement, demonstrate, illustrate, the accent of which has not yet assumed fixity as penultimate or antepenultimate; or for French loan-words like buffet, début, menu, débris, which hardly know as yet which direction they are to take. Some tolerance of diversity of usage is inevitable on the part of the skilled teacher of sounds. Within limits there is a mean between the deplorably careless and the pedantically precise. The teacher with the evolutionary point of view is likely to be a better guide than the teacher who has no resources beyond the pages of some orthoepy.

\section{III}

Graduate or undergraduate students who expect to become teachers of English, especially teachers of grammar and composition, should have followed the history of their language from the period before the Norman Conquest onward, its inflections, the growth of the vocabulary, the changes in spelling and pronunciationthis for the sake of the sounder ideas they will acquire concerning language. Academic courses in the history of the mother tongue should be broad enough to afford experience in all these fields.

If there is not time enough in the collegiate courses as ordinarily given, time may well be spared from translation, which is so often the staple of such courses. For nearly all the significant Old and Middle English monuments and for Chaucer, excellent translations are now available.
Translation is the phase of the study of older English in which the student requires least help. Further, when much time is given to translation, attention may well be paid to affording experience with a variety of literary types, both of poetry and prose, rather than to the exhaustive study of one or two monuments, often those of least cultural significance. There is great value in gaining first-hand experience with the various types of writing which interested the mediaeval mind. Few believe in the kind of history of the language which is disconnected from the reading of texts, the kind which is preoccupied with a history in the abstract, without the practice-material of actual reading to bring experience and orientation. But the reading of older monuments is demanded also in courses in the history of literature, while linguistic experience comes only from courses in historical grammar, if it be had at all. Time should be allowed for the student to watch development, to map out the whole field of changes, even if it must be done with a certain sweep of impressionism. The development of the language should be faced fully and fairly. If the question be asked, can this field be covered in a year's course of perhaps three hours a week, my answer is that $I$ think it quite possible, provided that the course in the history of the language accompaniess a semester of reading of Old English texts and a semester of reading of Middle English texts or of Chaucer. Much indeed can be done, on the oral side of the language, merely through a course in phonetics. Language is something that we use every day. It concerns us all. The cultivation of a scientific attitude toward it is an important phase of the instruction in English in our higher institutions.

It should be clear that the teacher needs the background of older language history 
to fint bis way and to keep bis linguistic balance, and (this should have special emphasis) to know bow to use the dictionary wisely. Whoever has followed the history of the language in an adequate manner emerges less rigid and narrow in his views than the person who has waved away the older for the merely contemporary, or who cares only for the cross-sectional, not the longitudinal view. Such a teacher knows that if Dryden's prose style or Addison's be held up as models, as they still are by many, it must be with the caution that many of their idioms and some part of their vocabularies are of the past. What is desirable is not that Dryden's or Addison's styles be imitated or reproduced, but that styles be fostered which are as reasonable and timely and standard for our own day as were Dryden's and Addison's for their day. The teacher trained in linguistics knows that the extremes of contemporary vogue may not last long enough for it to be wise for most writers to surrender to them. Such a teacher can steer a safe course between the Scylla of belated clinging to the outworn, and the Charybdis of undue faith in being up to the minute.
A very salutary thing, if it could be brought about, would be the destruction of the fear which is entertained by many teachers and students of courses in the history of the language, or in the study of older linguistic monuments. Many shrink with even more repugnance from archaisms in language than from obsolete modes of thought. They believe that grammatical courses have no bearing on the present. Intelligent teachers of language, like intelligent teachers of literature, concern themselves with both the older and the newer. They do not bury themselves in the past while studying the past, nor do they neglect and belittle it when dealing with the present. To do either is to leave the student half-educated and with narrowed outlook. Any teacher can use the living, no matter how far back may be the immediate material with which he deals. Collateral use of the contemporary, stimulation of interest in it, are possible at all times. They are indeed unavoidable for the well-equipped and enthusiastic teacher, whether of literature, history, or linguistics.

Louise Pound.

University of Nebraska. 